\title{
On some Diseases of the Sugar-Cane in the West Indies.
}

BY

ALBERT HOWARD, M.A., A.R.C.S., F.L.S.,

Late Mycologist to the Imperial Department of Agriculture for the West Indies.

\section{With Plate XVIII.}

TABLE OF Contents.

II. The 'Rund' Disease of the Sugar-Cane • • • . $\quad 374$

I. The Melanconium stage of Trichosphaeria Sacchari, Massee . 374

2. The macro- and micro-conidial stage of Trichosphaeria Sacchari,

Massee . . . . . . . . . . . 380

3. The ascigerous stage of Trichosphaeria Sacchari, Massee $\quad \cdot \quad \cdot 3^{83}$

4. The fungus causing the 'rind' disease of the sugar-cane in the West

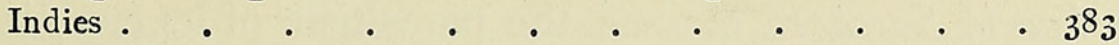

III. A Root Disease of the Sugar-Cane . . . • • . 39I

I. Characters of the disease . . . . . . . . $\quad$. 393

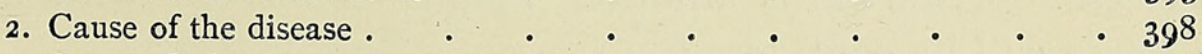

3. Some relations between the host and the parasite . . . . 403

4. Prophylaxis . . . . . . . . . . . 406

IV. Summary of Conclusions . . . . . . . . 407

V. List of Papers Cited . . . . . . . . . . 409

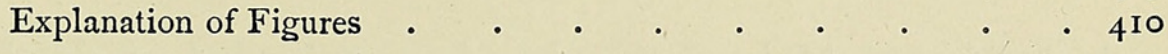

\section{INTRODUCTION.}

$\mathrm{T}$ the autumn of $\mathrm{I} 899 \mathrm{I}$ began an investigation into the 1 life-history of Trichosphaeria Sacchari, Massee (5), some of the earlier results of which were published in the 'Annals

[Annals of Botany, Vo1. XVII. No. LXVI. March, 1903.] 
of Botany' of December, I900 (17). The Director of Kew (16) contributed a paper on the sugar-cane disease of the West Indies, in which the literature of the subject is discussed, to the same number of this Journal. Since the publication of these papers I have continued the investigation of this fungus and the 'rind' disease of the sugar-cane, the results of which are given below.

During the last three years my attention has also been directed to a malady of the sugar-cane in Barbados, known among the planters as ' root disease.' Although it was found that this 'root disease' is only a general term covering several apparently distinct diseases of the cane, nevertheless by far the greatest portion which came under my notice proved to be identical in character and to constitute a definite disease. As the facts brought to light in the investigation of this malady have some bearing on the relations between the host and the parasite, and on the influence of the environment on both, an account of this disease may prove of general interest.

\section{The 'Rind' Disease of the Sugar-Cane.}

It will be convenient to deal first of all with Trichosphaeria Sacchari, Massee, the parasitism of its conidial forms on the sugar-cane, and the part played by these in the 'rind' disease. Afterwards another fungus connected with this disease will be considered.

\section{J. The Melanconium stage of Trichosphaeria Sacchari, Massee.}

A species of Melanconium has been recorded on dead and diseased canes in almost every country where the sugar-cane is cultivated. Thus in Engler and Prantl (18), M. Sacchari, Massee, is recorded on the sugar-cane in the Argentine. Apparently the same form is referred to by Massee (5) on the diseased sugar-canes forwarded to Kew from the West Indies in I893. Massee (8) also records it as occurring on diseased 
canes from Mauritius in 1894 , and on specimens of sugar-cane in the Kew Herbarium received from India and Borneo. Cobb (4) describes it in New South Wales under the name of Strumella Sacchari, Cooke, as causing a disease of the sugar-cane in the Clarence River district of that colony. Prillieux and Delacroix (11) report its existence from Martinique, Mauritius, and Tonquin, under the name of Coniothyrium melasporum (Berk.), Sacc. Went (13) has noted a species of Melanconium on dead and badly-diseased canes in Java. Tryon (20) records $M$. Sacchari in Queensland. I have frequently noted the fungus on dead and badly-diseased sugarcanes in many parts of the West Indies.

The conidia of this Melanconium are formed under the rind of the sugar-cane in stromata, from each of which a black hair-like filament composed of agglutinated spores is extruded. The resulting appearance of the cane and the germination of the spores are correctly figured by Massee (5), and by Prillieux and Delacroix (11).

The spores germinate in about twenty hours after sowing, and develop a septate branched mycelium in which fusion of the hyphae is extremely common. In about five days one or more stromata are formed in the drop, and after seven days the conidia of the fungus can be detected. This result was almost invariably obtained in hanging drops when the food material consisted of :--

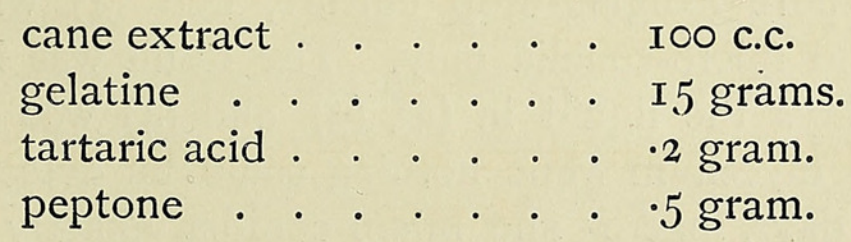

Beyond the formation of chlamydospores, figured by Went (13), in the hyphae, which were obtained in hanging drops, plate, and flask-cultures, I have never been able to induce this fungus to exhibit any other spore-formation than the conidia started with. Went (13) has described a third reproductive phase of the Java form, namely, large black globose conidia which are formed at the ends of the hyphae. 
In my first paper (17) on this subject an experiment is described in which pieces of healthy unsterilized cane were split open and infected with Melanconium spores, and with mycelium developed from a pure culture, and in which microand macro-conidia developed five days afterwards. On this occasion the control canes showed no such spore-formation. On repeating this experiment several times, however, it was found that micro- and macro-conidia occurred as frequently on the control canes as on those infected with Melanconium mycelium and spores, so that no proof of a genetic connexion between these forms, Melanconium and the macro- and microconidia, can be obtained from the experiment above referred to. Indeed, unless it can be shown that macro- and microconidia are developed in sterilized media from a single Melanconium spore or its mycelium, these forms must be regarded as two different Fungi.

'During the progress of this investigation it appeared interesting to determine what happens if flask-cultures of Melanconium spores are made in which macro- and micro-conidia are at the same time intentionally introduced.

Four sterilized flasks, containing the sugar-cane extract food-material mentioned above, were infected as follows (i) with spores obtained from a single-spore hanging-drop culture of Melanconium, (2) and (3) with similar Melanconium spores to which had been added macro- and micro-conidia from a single-spore hanging-drop culture, and (4) with similar macro- and micro-conidia only. The result was interesting. In two days the liquid in (2), (3), and (4) was filled with colourless mycelium while nothing could be detected in (I). In three days, macro- and micro-conidia, exactly like those started with, were developed in (2), (3), and (4), all three flasks being identical in appearance. On examining (2) the mycelium showed no traces of fusion of the hyphae, so characteristic of Melanconium, but the formation of macroand micro-conidia was extremely abundant. In seven days, stromata of Melanconium were evident on the surface of (I), but no formation of these bodies was noted in (3), which was 
to all appearances identical with (4). When allowed to compete together for the same food-material the macro- and micro-conidia vanquish the more slowly growing Melanconium form.

A corresponding result was obtained when sterile cane-slabs were infected in a similar way to the flasks above. Hence it is evident that if the results of flask-cultures of Melanconium spores are to be of any value in showing a genetic connexion between this form and the macro- and micro-conidia, such flasks must be infected from an undoubted pure culture, such as a hanging-drop colony developed from one Melanconium spore.

The degree of parasitism of the West Indian Melanconium was next investigated. In my previous paper (17), infection experiments on healthy sugar-canes are described, in which spores of this form from a pure culture were found to invade the tissues of a cane to some extent when introduced into fresh wounds, and the conclusion was drawn that this fungus behaves as a parasite and causes the common 'rind' disease of the sugar-cane. This conclusion has been found on further study to be inaccurate. Some of the infected canes in the experiments referred to were kept under observation for three months, when it was found on examination that the fungus had not spread more than 3 inches immediately above and below the wounds, and that it had not penetrated the tissues of the internode to any great extent. In no case could it be traced beyond the internode in which the wounds were made, neither did the canes in question show any of the well-known appearances of the 'rind' disease, such as the drying up of the leaves and the discoloration and shrinkage of the affected areas. On examining the mycelium it was found to have passed into a resting condition. The affected tissues were uniformly bright red in colour.

These results suggested the necessity of further infection experiments with this form. These were made, and the results were as follows :-

I. On November 27, eighteen healthy Bourbon canes were C c 
selected. Six were used as controls and twelve were inoculated at wounds, six with Melanconium spores from a pure culture and six with similar spores and food-material. The places where the wounds were made were cleaned with alcohol, and flamed with a spirit-lamp. The holes were cut with a sterile knife, and after inoculation were bound up with sterilized tape which had been soaked in paraffin wax. The control canes were treated in a similar manner, but in this case no spores were introduced. On December 28 these canes were examined. In no instance had the mycelium spread to any extent, except immediately above and below the wound where it reached the nearest nodes. The affected tissues were bright red as before, and the canes exhibited no trace of the 'rind' disease. The controls showed no infection, although the cells round the wound were bright red and the bundles cut through showed gumming in the large vessels. Possibly this formation of gum is an adaptation on the part of the cane to prevent Bacteria and Fungi passing into the vessels where it is wounded.

2. On December I0, four healthy White Transparent canes were inoculated with Melanconium spores from a pure culture at wounds made with a sterile knife as above. Four other canes from the same stool were used as controls. Thirty days afterwards the canes were examined. In all cases the tissues were brownish-red above and below the wounds, but no difference was evident between the inoculated canes and the controls in this respect. On examining the inoculated canes it was found that the mycelium of the fungus had in all cases spread in the tissues immediately above and below the wounds as far as the nearest nodes, but it could not be traced beyond the vertical column of tissue containing the wound and bounded by the nodes above and below this aperture. The characters of the invading mycelium were identical with those of the hyphae developed in artificial cultures of Melanconium spores. In no case was any mycelium noted in the control canes.

3. On December I9, four healthy White Transparent canes 
were doubly inoculated-at wounds in an upper and a lower internode-with actively growing mycelium of the fungus from pure cultures. Four other canes were used as controls. On January 22, the results were almost identical with those obtained above.

4. On December 2I, four healthy White Transparent canes were doubly inoculated, at wounds made at an upper and a lower internode, with Melanconium spores from a pure culture. On January 27 , it was found that the fungus had not penetrated beyond the column of tissue containing the wound and bounded by the nodes above and below. The control canes showed no infection.

These experiments point to the non-parasitic character of the West Indian Melanconium towards the sugar-cane. The behaviour of this form, therefore, closely resembles that of the Java Melanconium studied by Went (13), and the whole of the evidence points to its being a saprophyte.

A careful examination of a large number of canes attacked by the 'rind' disease showed that after the outer leaves begin to dry up at their margins - the first indication that canes are attacked by this disease-they gradually die in from four to eight weeks. When the leaves are about half dried up, the black filaments of Melanconium can be detected bursting through the discoloured areas of the stem. In many cases this is the only fungus which at this stage can be seen on the affected stems. The inoculation experiments described above, however, point to the conclusion that Melanconium cannot be regarded as the cause of the 'rind' disease.

The difficulty was solved by the study of another fungus which was found on the affected canes, and which in previous studies of the West Indian 'rind' disease had been overlooked. Before considering this fungus it remains to deal with the macro-, micro-conidial, and the ascigerous phase of Trichospheria Sacchari, Massee. 
2. The macro- and micro-conidial stage of Trichosphaeria Sacchari, Massee.

This form is widely distributed throughout the West Indian Islands, and also occurs in Surinam, British Guiana, and Java. It has been described and figured by Went $(7,13,14)$, under the name of Thielaviopsis ethaceticus, Went. This observer found that it gave rise in Java to a disease of cane-cuttings known as the 'pine-apple' disease. Massee (5) has also described and figured it, and has shown that it is parasitic on the cane. The development of both macro- and micro-conidia from a single conidium of these two kinds is described in a previous paper (17).

In addition to the formation of these conidia at the ends of the hyphae, similar spores are also formed inside the vegetative hyphae. In rare instances chlamydospores are formed in the mycelium.

As in Java, the fungus in the West Indies by no means confines itself to the sugar-cane. It is common on bruised fruits such as bananas and pine-apples, and frequently destroys many of the pine-apples sent from Antigua to London during the voyage. It is probable that it gains access to them at bruised surfaces.

As mentioned above, this fungus is principally of importance in Java on account of its causing the 'pine-apple' disease of cane-cuttings, and, as mentioned by Went (13), is not very common on growing canes. Accordingly when examining some of the cane-cuttings which died out or failed to grow at all in Barbados during the planting-seasons in December, I900 and. I 901 , and which amount to 25 to 50 per cent. of those planted, depending on the season, this fungus was especially looked for. In a large number of cases Thielaviopsis was found in these dead cuttings, and when it did not occur other Fungi were noted which appeared to have something to do with the arrest of growth of the cuttings. It appeared likely, after examining many hundreds of these dead cuttings, that Fungi are instrumental in destroying them. Of these, Thielaviopsis was met 
with to the greatest extent. The disease of cane-cuttings in the West Indies appeared to be almost identical with that of Java.

It was first of all necessary to prove that the Thielaviopsis which attacks standing canes is identical in all respects with that found in diseased cuttings in the ground. The fungus from dead cuttings was cultivated from a single spore, and its development was found to be identical with that of the fungus in growing canes. Next the spores of the former fungus were placed on the cut ends of 100 cuttings before planting. Four weeks afterwards, all these cuttings were destroyed by the fungus, and on being split open were characterized by the odour of ethyl acetate and the development of numerous conidia of the fungus. A like number of uninfected cuttings were planted at the same time, all of which grew normally. Cross inoculation experiments were now made. The fungus from cuttings was found to infect the standing canes and that from the cane to destroy cuttings. Hence it was clear that only one fungus was being dealt with.

A study of the means of protecting cane-cuttings from this fungus (21) showed that dipping the cuttings in Bordeaux mixture and then tarring the ends is an efficient method. Cuttings treated in this way developed readily even after being dipped in water containing the spores of the fungus.

It was next desirable to repeat the experiments described in a former paper (17) on the parasitism of this fungus on the cane. Went (13) states that the fungus can behave as a wound parasite. According to Massee (5), the parasitism of the fungus would appear to be of a more pronounced character. It appeared necessary to find out whether the fungus can easily infect a cane at the old leaf-bases, and also to compare the infection of the cane in the parts rich in cane-sugar with those near the growing-point which are poor in this substance (12). The following experiments were therefore made :-

I. On December 26, four healthy canes were inoculated at wounds, both at an upper and a lower internode, with pure 
cultures of this fungus, adopting the precautions described above in the experiments with Melanconium. In two of the canes inoculation was made with spores, in the other two with growing mycelium from pure cultures. Four similar canes were used as controls. On January 22, one of each of these canes was examined. At the lower internodes of each of the inoculated canes the mycelium had spread about I 2 inches above and below the puncture, and macro-conidia were developed in the hollow centre of the cane. The affected tissues were slightly reddish, and the odour of ethyl acetate was very marked. At the upper part of the cane the fungus had, in each case, completely spread through the infected internodes, the tissues of which were black on account of the development of large numbers of macro-conidia in the cells. The control canes showed no infection. On January 27 , the rest of the canes were examined. Both the inoculated canes gave practically the same results as those examined five days earlier.

2. On December 26, spores from a pure culture were placed on the uninjured leaf-bases at upper and lower nodes of two canes. On January 2, one of these canes was examined, when it was found that infection had taken place at the two nodes. At the lower node, the mycelium of the fungus had invaded about 3 feet of the cane. Macro-conidia were developed in the centre, and the odour of ethyl acetate was evident. At the upper node about 6 inches of the stem were infected, and the tissues were black through an excessive development of macro-conidia in the cells. The other cane was examined on January 27 , when it was found that infection had only taken place at the upper node, when about 8 inches of the cane were invaded as in the previous case.

3. At the same time spores and food-material were placed on the uninjured internodes of four sound canes and covered up with waxed tape. A month afterwards no infection could be detected.

The result of these experiments leaves no doubt that Thielaviopsis is capable of pronounced parasitism on the 
sugar-cane, and can infect both at wounds and at old leafbases. The contrast between the behaviour of this form and Melanconium is most marked.

The fungus has been cultivated in Barbados for two years under a wide range of conditions as regards food-materials, but in no case has any other spore-formation than those mentioned above been detected. Flask-cultures have been kept under observation for eighteen months, but no trace of Melanconium spores or perithecia has been observed. These results agree with those obtained by Wakker and Went (14) in Java.

\section{The ascigerous stage of Trichosphaeria Sacchari, Massee.}

Several thousands of rotten canes have been examined in Barbados and other islands during the last three years, but in no case have the perithecia described for this form been found. Several other Ascomycetes, however, have been noted, one of which is distinctly parasitic. The perithecia of this fungus, however, are formed underneath the rind of the cane.

\section{The fungus causing the 'rind' disease ${ }^{1}$ of the Sugar-Cane in the West Indies.}

Very characteristic are canes attacked by the 'rind' disease in the West Indies. In Barbados the disease appears about November or December, and increases rapidly in amount up to March and April, when the canes are reaped. It makes its appearance earlier in plant-canes than in rattoons, and attacks sweet canes, like the Bourbon, to a much greater extent than some of the seedlings. I have, however, noted the disease on a large number of the seedling and other canes, which have now almost entirely replaced the Bourbon in Barbados on account of the ravages of this disease. It is quite common on the White Transparent. The first symptom of the malady is the drying up of the leaves, which commences

1 As contrasted with the disease of cuttings caused by Thielaviopsis ethaceticus. 
at the margins of the older ones and gradually spreads to the centre of the bunch in from four to six weeks. As soon as this drying of the leaves is well marked, the stem of the cane shows a brown discoloration in one or more places, after which the rind shrivels up and the discoloration rapidly extends in all directions. On splitting such canes the tissues are seen to be of a general reddish colour, in which darker red areas can be seen. Very frequently these darker regions contain definite white centres, elliptical in vertical section. The major axis of the ellipse is at right angles to the main axis of the cane stem. The appearance (Fig. 2) coincides exactly with that figured by Went $(6,14)$ in his writings on the 'Red Smut' disease of Java. Infection seems to take place in many cases at the tunnels made by boring-insects, but in a good many instances it appears to have started at the old leaf-bases. Two Fungi are very common on such diseased canes-the Melanconium described above, and a second form which is not very often seen in the earlier stages. This second form occurs as minute, black, velvety patches on the outside of the cane, generally just below the leaf-base, or on the sleeping roots above the node (Fig. I). These patches are stromata bearing dark hairs. At the base of the hairs, crescent-shaped, unicellular conidia are given off from short basidia. The infected tissue contains colourless mycelium, in which fusion of the hyphae is very common and in which the contents appear as a row of circular oily drops. In the older portions of the affected tissue, brown chlamydospores are to be seen in the hyphae, which also turn darker in colour. All these appearances agree with the fungus causing the 'Red Smut' disease of Java described by Went $(6,14)$.

In view of the result of the inoculation experiments with Melanconium, described above, it appeared desirable to cultivate this second fungus and to study its parasitism. This was done, and hanging-drop cultures containing a single spore were made by Marshall Ward's method (3), using the caneextract medium given above. 
The spores germinate in three hours after sowing by sending out a colourless hypha from one end, after which a second hypha is developed at the other end. These grow rapidly, become septate, branch, and fuse very readily (Fig. 3). When three days old, conidia were developed from the mycelium by a process of budding. These conidia are smaller $(25 \times 2.5 \mu)$ than those formed at the stromata, and are identical with those produced in great numbers when a piece of fresh cane attacked by the 'rind' disease is split open and placed in a closed chamber. Stages in their formation are shown in Fig. 4. They vary very much as regards shape and size.

When five days old, dark-brown, irregularly-shaped chlamydospores were noted in the hyphae, especially at the ends. They measure $I 5$ to $25 \mu$ in diameter and are represented in Fig. 5 .

When six days old, stromata appeared in the drops, at which sickle-shaped conidia, measuring 30 to $45 \times 5 \mu$, were formed. Stages are shown in Fig. 6. Only very rarely were the dark-brown hairs, characteristic of the stromata of the fungus on the sugar-cane, noted in these hanging-drop cultures. When they occurred they measured 100 to $15 \circ \times 4 \mu$ and were four to five septate. No further developments were observed in hanging drops.

Next, cultivations of this fungus were made by infecting sterile pieces of sugar-cane with spores from a hanging-drop culture grown from one spore. In three days the slabs were covered with a beautiful white mycelium, and in fifteen days dark-coloured dots were noted, which were found to be stromata bearing dark-brown hairs and numerous conidia exactly like those on the cane.

These cultures were repeated several times, when it was found that the time of appearance of the black stromata varied between five and eighteen days according to the size and character of the cane-slabs.

A similar result was obtained in flask-cultures, using the cane-extract medium. Stromata appeared on the surface of the flasks in from fifteen to twenty days. 
In tubes containing ro c.c. of the cane-extract, a similar development occurred, except that stromata appeared on the surface in from four to five days.

In none of the cultures were any further spore developments noted, and no trace of the formation of any of the phases of Trichosphaeria Sacchari, Massee, was detected.

It now remained to perform inoculation experiments with pure cultures of this fungus on healthy sugar-canes. These were as follows :-

I. On December 4, six healthy canes in the same stool were inoculated at wounds made in internodes about the middle of the stem and also at upper leaf-bases, with spores from a pure culture of the fungus. The precautions, described above, to prevent the entry of other spores were taken, and six other canes were used as controls. On December Io, one of the inoculated canes showed that infection was taking place at the wound, but no result was observed at the leafbase. On December I6, a second cane was examined, when distinct infection was observed in the tissues of the internode where the wound was made and also at the upper leaf-base. On December 26, two more canes were examined. No infection was detected at the leaf-bases, but at the wounds very definite indications of the 'rind' disease were noted. The leaves were beginning to dry in the characteristic manner, and on splitting open the canes infection was apparent in four of the internodes, where the red blotches, with white centres, were evident. The invading mycelium was characterized by its branching and oil-drops, and agreed exactly with that seen in canes attacked by the 'rind' disease. The remaining two canes were also drying at the top and were obviously infected at the wounds. They were used for the experiments with Melanconium described below. In this experiment one of the controls became infected with the fungus; the other five gave negative results.

2. On December Io, six canes were inoculated in a similar manner to those in the above experiment, and six others were used as controls. On December 28 , one of the inoculated 
canes showed infection at the wound, but not at the leaf-base. On January 22, two of the inoculated canes showed that at the wounds the fungus had invaded two of the internodes and had produced the characteristic red blotches with white centres. In one case infection had also taken place at a leaf-base. The other three canes, in which infection at the wounds was very evident, were used for the experiments with Melanconium described below. The control canes gave negative results.

3. On December 19, four canes were doubly inoculated at wounds made in an upper and a lower internode, with mycelium from a pure culture of the Colletotrichum. As before, controls were employed and precautions taken to introduce only one fungus. The object of this experiment was to determine the comparative effect of the fungus on those portions of the cane which are very rich and very poor in sugar. On January 22, a cane was examined, when it was found that the fungus had invaded 16 inches of the upper part, which showed the characteristic markings, but had not spread beyond the internode at the lower wound. The remainder of the canes were examined five days later. In all cases infection had taken place to about the same extent, the length of cane affected varying from 18 to 24 inches. The characteristic red blotches with white centres were abundant.

4. On December $3^{\mathrm{I}}$, four canes were inoculated with spores from a pure culture of the Colletotrichum as follows. In two cases the canes were doubly inoculated at upper and lower leaf-bases, and in the other cases at wounds in upper and lower internodes. Two control canes were also used. On January 22, the canes which had been inoculated at leaf-bases showed that infection had taken place at both the upper nodes and at one of the lower nodes. At the upper part of both canes the stromata of the fungus were abundant on the affected rind at the nodes above and below the point of inoculation. In each case about 9 inches of the cane were affected and the red blotches were abundant. A similar 
result was observed in the case of the cane where the fungus had also infected at a lower node but no stromata were evident on the rind. On January 23 , the canes inoculated at wounds showed that in all cases infection had taken place, and stromata had formed on the outside at the upper affected regions. From 12 to 18 inches of the cane were invaded at each wound. The controls gave negative results.

The above inoculation experiments were carried out with canes during the ripening period and after active growth in size had ceased. The results obtained, while indicating that the fungus is a wound parasite, nevertheless do not conclusively show that it is capable of overcoming tissues still capable of growth and development. Accordingly, further experiments were made on plant-canes ${ }^{1}$ about six months old which were in a vigorous state of growth. In all cases inoculation was performed in developing internodes which were then not more than $I$ inch in length. The experiments were as follows :-

5. On June 20, three young canes were inoculated by placing seven days old, actively growing, mycelium, from a pure culture in the sugar-cane extract medium, into wounds made in the centre of a lower internode then about threequarters of an inch in length. Care was taken to introduce only one fungus and to shut off the apertures from the air by means of sterilized waxed tape. Three similar canes were used as controls. Two months afterwards the canes were examined. In the first case, the infected internode had grown to $2 \frac{1}{2}$ inches in length, and on splitting open the cane this and the internode below were found to be generally reddish in colour with the elliptical white areas, characteristic of the 'rind' disease, well represented. About 4 inches of the cane were invaded by mycelium, which agreed with that of C. falcatum. A closely similar result was obtained in the other two inoculated canes, but the controls showed no infection.

1 The first crop of canes raised from cuttings are known in the West Indies as 'plant-canes.' 
6. On June 23 , the above experiment was repeated on two similar canes. Two months afterwards two internodes were, in each case, found to be completely invaded by the fungus which had produced all the characters of the 'rind' disease.

7. On June 27 , four canes about six months old, growing in tubs, were inoculated with pure cultures of the fungus, three at wounds in the internodes, the other at a leaf-base. On August 19, one of the canes inoculated at a wound exhibited the characteristics of the 'rind' disease in the infected internode, but the other three and the controls gave negative results.

8. On June 23 , three vigorous canes about six months old, growing in the field, were inoculated at leaf-bases, from which the adhering green leaves had been torn, with six days' old mycelium from a pure culture. Afterwards the nodes were covered with sterile waxed tape. On August I9, one of the canes gave a negative result, but the other two showed distinct infection. In one case, 5 inches of the cane were invaded, in the other about $2 \frac{1}{2}$ inches.

These experiments show conclusively that the Colletotrichum is capable of more than mere wound parasitism. It is able to overcome tissues capable of active growth. At the same time it can thrive readily as a saprophyte in artificial media and pass through its whole development thereon. It occurs in the West Indies every ripening season as a parasite. It would seem to be therefore intermediate between a hemisaprophyte and a hemi-parasite and not to belong strictly to either of these classes.

Further, it is clear that this fungus and not Melanconium is the cause of the 'rind' disease of the sugar-cane.

On referring this fungus to its systematic position it is evident that, in the absence of any higher fructifications than the stromata described, it must be placed in the Fungi Imperfecti and that it falls into Corda's genus Colletotrichum (18). From its characters and its parasitism on the sugar-cane it evidently agrees with $C$. falcatum, Went $(6,14)$, a form which causes the 'Red Smut' disease of the sugar-cane in Java. 
Thus the 'rind' disease of the West Indies and the 'Red Smut' of Java are identical. This conclusion was strengthened by the examination of specimens of sugar-cane, said to be attacked by 'rind' disease, from other parts of the West Indies and Surinam. In all cases the characters of the disease were identical with those given above, and most of the specimens showed both Melanconium and Colletotrichum. Further, careful examination of many of the cane-fields of St. Vincent in January, 1902, where the Bourbon is almost exclusively cultivated and where the 'rind' disease makes its appearance every year in December, showed that the disease was identical with 'Red Smut' and that the fungus Colletotrichum falcatum was present.

The fungus appears to be widely distributed. In addition to the West Indies it occurs in Java, Madras (19), and also in Queensland (20).

The remedies suggested by Went (13) for the treatment of this disease in Java would seem to apply to the circumstances of the West Indies.

Since Melanconium always appears on canes attacked by the 'rind' disease it seemed probable that it must infect the canes after they are diseased. Accordingly the effect of this fungus on a part of a sugar-cane attacked by Colletotrichum was compared with its effect on the still healthy portion. The results were as follows:-

I. Two canes which had been inoculated on December 4 with spores of Colletotrichum, and which showed from the outside that infection had taken place, were reinoculated on December $2 \mathrm{I}$ at the affected region and also near the base, in the still healthy tissue, with spores of Melanconium from a pure culture. On January 23 , it was found that at the upper part numerous stromata of Melanconium had developed, but at the base infection had not taken place.

2. On December 19, three canes, which had been inoculated at the upper parts with spores of Colletotrichum nine days previously, were reinoculated with Melanconium spores from a pure culture. A second inoculation with these spores was 
made at the base of these canes in the still healthy portion. On January 27, Melanconium stromata were evident round the upper wounds, but no infection had taken place below.

These experiments show that the part played by Melanconium in the 'rind' disease of the sugar-cane is that of a follower of Colletotrichum, and that it only invades previously diseased canes.

\section{A Root Disease of the Sugar-Cane.}

Since the rainfall of Barbados and the local agricultural practice have a distinct bearing on the root disease under discussion, some reference to these subjects seems necessary.

There is a well-marked dry season in the spring as will be seen from the following table, in which the mean monthly rainfall at one of the stations is given from 1892 to $190 \mathrm{I}$. The average annual rainfall during this period was 62.85 inches, but the total precipitation on the highlands (above 400 feet) was about Io inches more than that on the lowlands.

Mean monthly rainfall from 1892-1901 both inclusive.

\begin{tabular}{|c|c|c|c|c|c|c|c|c|c|c|c|c|}
\hline Month & Jan. & Feb. & Mar. & Apr. & May & June & July & Aug. & Sept. & Oct. & Nov. & Dec. \\
\hline $\begin{array}{c}\text { Rainfall } \\
\text { in inches. }\end{array}$ & 3.12 & I.65 & 2.72 & 2.53 & 3.42 & 5.03 & 6.09 & 8.24 & 9.08 & 7.28 & 7.88 & 5.81 \\
\hline
\end{tabular}

Planting is usually carried out in November and December and reaping takes place about eighteen months later, from March to June in the second year after planting. Usually the old stumps are allowed to produce a second crop of ' rattoons,' the growing period of which is about a year. On the red soils in the highlands, two or three of these rattoon crops are obtained, but in the lowlands the canes only rattoon once at the most.

As a rule the first crop of canes is healthy, at any rate till growth is completed and the 'red smut' disease makes its 


\section{Howard.-On some Diseases of the}

appearance during the ripening period. Sometimes, however, the young canes do not respond to the early rains of the wet season in June and July, practically making no growth and remaining dwarfed. Instead of the twelve to fourteen broad green leaves of normal canes the affected shoots bear from six to ten pale-green narrow leaves, the oldest showing a tendency to dry up from the apex and margin. Even after rain, when the soil contains much moisture, the young leaves in the centre of the tuft assume the vertical position and partly fold up by the inrolling of the two halves of the lamina, in the manner described and figured by Wakker (9). This device for preventing over-transpiration is only made use of by healthy canes during drought, but in those in question it is constantly apparent and at once suggests water starvation. The stunted canes never recover, but struggle on, throwing up large numbers of shoots from the buds at the base of the stem. These new shoots in turn become affected like the parents and a clump of dwarfed canes results, resembling one of the phases of the 'sereh' disease of the sugarcane in Java (14). The diseased canes occur in circular patches, which, however, are not sharply marked off from the normal areas, but gradually shade off into them.

It is in the second-crop canes or rattoons of the lowland districts especially that the trouble indicated above is to be seen on the large scale. Often the whole field is uniformly affected, and the contrast between it and a neighbouring firstcrop field is most striking. In the former case, the narrow, pale-green, erect and partly folded-up leaves are few in number and the clumps of cane do not meet in the rows; in the latter, the leaves are broad, dark-green in colour, and bend to the breeze with the lamina flat and fully exposed to the light. Here the canes meet fully in the rows, and, when viewed from above, look like solid masses of green. The striking difference between first and second crops on the lowland areas is so general that it seems to have been accepted by the planters as part of the ordinary course of things. The general impression seems to be that the soil is not suited 
to rattoons. On the red soils in the highland districts this dwarfing of the rattoons, although to be noted here and there in the second crop, is not so general as on the black soils of the lowlands. It makes its appearance, however, to an increasing extent in the third and later crops, and finally leads to the throwing out of the fields. Locally, the red soils of the highlands are known as rattooning soils, while those of the lowlands, although giving very good first crops, are not regarded as specially suitable for a second crop.

The comparative failure of rattoon crops was found on examination to be due, in most cases, to a definite root disease, some account of which is given in the following.

\section{Characters of the Disease.}

Apart from the peculiarities of the leaves of the dwarfed canes and their marked tendency to throw up shoots from the base, which have been already referred to, there are other characteristics to be observed on a closer examination. As a rule, a healthy cane sheds its old dry leaves as growth proceeds, but in those in question the leaf-sheaths of the dead lower leaves adhere firmly to the stem, being cemented thereto by a white, musty smelling, fungoid growth. Such canes ean moreover be pulled out of the ground with ease, when they are seen to possess very few roots. They are - besides very much lighter in weight than healthy canes of the same size. On stripping off the dead leaf-sheaths at the base of the stem, it is found that most of the roots have either not developed or else have ceased to grow when about a $\frac{1}{4}$ to $\frac{1}{2}$ an inch in length, when they are brown in colour and corky to the feel. The rind of the cane immediately over the undeveloped roots is marked by brownish or blackish spots. Considerable force is required to remove the leaf-bases from the part of the stem covered by the soil and to clear the nodes, as the white fungoid growth referred to binds the whole into a solid mass. A portion of the lower part of a sugar-cane stem showing the abnormal development of the lower buds and the aborted roots is shown in Fig. 7, while in $\mathrm{D} d$ 
Fig. 8 the dwarfed roots from a similar portion of an affected cane are shown on a larger scale. On splitting open the lower portions of the stem, the vascular bundles are often reddish, while towards reaping-time cavities occur in the internodes, in which, when the canes are nearly dead, white mycelium can be detected with the naked eye. The still living leafsheaths are covered with a layer of white matted mycelium, and reddish spots are common thereon. Black elliptical areas, surrounded by a reddish border, are also abundant on the leaf-sheaths, which are in some cases slimy to the feel on the inside after rain, when hard, yellowish, spherical bodies, about the size of a small pea, attached to the outside of the leafsheaths by whitish threads, are to be seen. Colonies of small, yellowish-white toadstools are to be met with after heavy rains on the lower parts of the diseased shoots (Fig. 9). These persist only for a day under the most favourable circumstances, and for this reason appear to have escaped attention hitherto. Specimens for examination, or for the production of spores, are best collected as soon after daybreak as possible, as the sun dries them up very rapidly.

All these characters are to be made out on canes affected by this disease. The matted white mycelium on the dead leaf-sheaths, the reddish areas on those still alive, and the aborted and undeveloped roots are constant characters, while the black elliptical areas, although common, are not always present. The yellow spherical bodies and the slimy leaf-sheaths are comparatively rare.

The white fungoid growth which cements the old leafsheaths to the stem proved to be a branched, septate mycelium, very variable in diameter, which exhibited the clamp-connexions chiefly met with among the Basidiomycetes.

A similar mycelium was found around the aborted roots, in fact, these were often imbedded in a thick felted mass of hyphae. It was further detected in great quantity between the still living leaf-sheaths and in the cells of the reddish areas noted on these, and also in the tissues of the aborted roots themselves. 
Longitudinal sections of the dwarfed roots showed that the root-cap and cortex were invaded in all directions by a mycelium characterized by clamp-connexions and brown, thick-walled, chlamydospore-like bodies (Fig. IO). These tissues and the whole of the periblem were dead, much disintegrated and dark brown in colour in many places. The pleurome was often invaded by similar mycelium, and the growing-point destroyed. Attempts were frequently made by such roots to branch, but the secondary roots were usually destroyed before the cortex of the parent root was penetrated. The beginning of such attempts is shown in Fig. 11 .

The undeveloped roots, which were characterized by brown marks in the rind of the cane immediately over them, were found to be destroyed in a very similar manner to those in which growth had been arrested shortly after penetration of the rind. Longitudinal sections showed that the periblem, and often the pleurome too, were invaded by the abovedescribed mycelium. The root-cap, digestive sac, and growingpoints were in all cases destroyed (Fig. I1). The mode of entry of the fungus into the developing root varies. In some cases it passes from the exterior through the digestive sac and root-cap and invades the growing-point tissues direct. In others, it passes between the young root and the surrounding tissue of the stem and invades the periblem from below, passes upwards, and finally overcomes the growing-point.

No matter whether the roots are destroyed just after penetration of the parent stem or before this is accomplished, the result is the same, namely, the loss of a possible means of supplying the cane with water and minerals from the soil. When, as in most cases of this disease, by far the greater number of the roots in the below-ground portion of the stem are destroyed in this way, as well as those for some distance above the ground, it is clear that recovery is out of the question.

If the development of the shoots which arise from the buds at the base of the parent stem is followed, it is found that here too the leaf-sheaths become cemented to the stem by $\mathrm{D} d 2$ 
the white mycelium, and that the majority of the roots are destroyed as before. It sometimes happens that these shoots die off, when they are found to be penetrated by this mycelium in all directions.

The below-ground portions of the older shoots sometimes contain this mycelium and show reddening and extensive gumming of the vascular bundles. As the reaping-period approaches and the supply of water in the soil falls off, large cavities are formed in the centre of the internodes, in which, in cases where the canes are drying up, the white mycelium luxuriates. In a short time such dying canes become infected by the saprophytic fungus Melanconium referred to above.

The dark-coloured, elliptical areas on the living leafsheaths of many of the canes attacked by this disease were found to be due to the conidiophores and conidia of the fungus Cercospora vaginae, Krüger, which is described and figured by Wakker (14) and also by Krüger (15). As in Java, this parasite is extremely common in the West Indies on the leaf-sheaths of the sugar-cane, and is to be met with on both vigorous looking and obviously diseased canes. As it spreads from the older to the younger leaf-sheaths, when these are in contact, with the greatest ease, canes once infected are never able to get rid of this parasite. As the upper portions of the cane embracing the main growing-point ('tops') are generally used as plant-material, and as the leaf-sheaths adhering to the cuttings are often covered with this fungus, it is easy to understand that the young shoots become infected and that this disease is reproduced in every new stand of canes. By following the young shoots arising from the cuttings it can be readily seen that reinfection takes place almost before the young stems are above the ground, and that as far as this disease is concerned, parasite and host are planted together.

The hard, spherical, yellowish, pea-like bodies noted on the leaf-sheaths of some of the diseased canes were found to be sclerotia. Identical structures, accompanied by reddening of the leaf-sheaths and sliminess on the inner side thereof 
after rain, were found on other canes not attacked by root disease. In such cases the rind of the cane below the internode was bright red in colour, partly disintegrated and invaded by a mycelium identical with that attached to the sclerotia. The characters of these sclerotia and of their mycelium and the appearance of the affected canes were found to agree in all respects with Went's 'red-rot' disease in Java (14).

The occurrence, therefore, of the sclerotia and of Cercospora vaginae on the leaf-sheaths of the diseased canes is accidental. It is, however, a good example of the simultaneous existence of two or more parasites on the same cane-a frequent circumstance in the cane-fields of the West Indies.

The toadstools noted on the diseased canes are yellowishwhite in colour, the pileus varying in diameter from 10 to I $8 \mathrm{~mm}$. ; the curved stipe being about equal in length to the diameter of the cap (Fig. 9). As these fructifications reach maturity, the pileus becomes flattened, and in some cases depressed to such an extent that the toadstool has the shape of a wine-glass, the gills being on the outside of the cup. The lamellae run right up to the centrally-disposed stalk, but are not attached thereto. They are arranged in a stellate manner and may branch once or twice towards the margin of the pileus. The spores are milky white in the mass, irregular in shape with one end somewhat elongated. They arise from the basidia in the usual manner, measure 15.5 to 18 by 4.5 to $5 \mu$, and, when fresh, contain vacuolated protoplasm and oil-drops. The toadstools dry up quickly and become tough, but they revive when moistened. These characters indicate that this form belongs to Fries' genus Marasmius, which, according to Saccardo, includes 450 species, mostly saprophytes of the tropics and sub-tropics.

It appeared probable that there was a genetic connexion between these toadstools and the white mycelium with clampconnexions found on the old leaf-sheaths, in the aborted roots and in the reddish-coloured portion of the still living leafsheaths. Further, there appeared to be some likelihood that 
the mycelium referred to was the cause of the non-development of the majority of the roots, and therefore of the root disease under consideration. Since Cercospora vaginae and the sclerotia fungus do not always occur on the diseased canes, but give rise to separate diseases, and moreover as their mycelium does not exhibit clamp-connexions, these fungi could be left out of consideration until the part played by the apparently basidiomycetous mycelium had been investigated. Steps were therefore taken to obtain pure cultures of the toadstool spores and of the white mycelium, and also to perform inoculation experiments therewith on healthy canes.

\section{Cause of the Disease.}

Spores were obtained by placing fresh toadstools in sterilized glass dishes with grooved covers. In a few hours a white spore print appeared on the floor of the chamber, the spores of which were employed in making hanging-drop cultures.

In the cane-extract food-material given above the spores germinated in ninety minutes, sending out a narrow germtube, which quickly branched and into which the contents of the spore passed. The earlier stages in the process are shown in Fig. I 2. In two days, stellate colonies of colourless, branched, septate mycelium developed, the protoplasm of the apical ends being brilliant and homogeneous. When three days old, the mycelium began to grow down into the air and to exhibit abundant fusion of the hyphae. At this point the formation of clamp-connexions was first noted. Stages in the process, which occupied about an hour, and which agrees with that observed by Brefeld (1) in the case of Coprinus stercorarius, are shown in Fig. I3. The development of aërial hyphae continued, until a dense tuft of pure white mycelium resulted. When about seven days old crystals began to be formed at the growing ends of the hyphae, and after twelve days some of the filaments deliquesced into a gelatinouslooking material, which probably explains the cementing 
action of the fungus on canes. Several of the drops contained one spore, and this fact and that of the aerial development of the hyphae in the hanging drops enabled pure cultures to be obtained.

These were made on pieces of sterile cane, on bundles of sterile leaf-sheaths, and also with wire baskets of earth containing a portion of a young cane-shoot, the whole having been sterilized. In all cases the results were the same, namely, the production of a brilliant white mycelium, which showed a tendency to collect into feathery strands on the walls of the glass tubes and which, in several cases, produced dark-coloured, branched rhizomorphs when about nine months old (Fig. I4). Portions of these and of the white mycelium in the culture when ten months old were found to be alive, and to develop a growth of white mycelium when transferred to a fresh substratum. Thus the fungus can readily pass into a resting condition, a fact of some significance from the practical standpoint as will appear later.

Cultures were now made with the white mycelium characterized by clamp-connexions found on the leaf-sheaths of diseased canes. By placing some of these leaf-sheaths in a moist chamber the white mycelium thereon produced tufts of hyphae in a few hours, which were used to infect hanging drops. In this way cultures were obtained which were uniform in appearance, and which agreed with those from the toadstool spores. The further results on cane-slabs, cane-trash, and in the sterilized baskets of earth were identical with those obtained above with the hyphae from the toadstool spores. It appeared, therefore, very probable that the toadstools are genetically connected with the white mycelium on the leaf-sheaths of the diseased canes. Complete proof was obtained later when identical toadstools were developed from the mycelium derived from spores and from that on the leaf-sheaths.

The rhizomorphs (Fig. 10) obtained in these cultures were found to have a definite rind made up of dark-brown, thickwalled, septate hyphae arranged somewhat irregularly, which 
enclosed a medulla of thin-walled, parallel, septate, colourless mycelium. The dark strands shaded off into loose, white, feathery growths. These latter are very common in cultures and also on cane-cuttings infected with this fungus. They differ markedly from those associated with the sclerotia of Went's 'red-rot' disease.

In no case were toadstools obtained in the above cultures. They were, however, produced in the infection experiments described below.

With one exception three series of inoculation experiments were made in which the infecting material was obtained from different sources in each case. Thus, in addition to using the cultures obtained from a single toadstool spore and those from the white mycelium on the leaf-sheaths, pieces of the leaf-sheath, obtained from diseased canes, were also employed.

Experiment I. In the first instance, three young rattoon shoots, about a foot high, were selected for the experiment. After washing with water, portions of six days' old mycelium (developed from a spore) growing in the cane-extract medium given above, were placed in the axil of one of the lower leaves of two of the shoots and the whole was covered with a clean lamp chimney, cotton-wool being packed around the shoot at the upper end. The third shoot was used as a control. In seven days, the leaf-sheath, on which the mycelium was placed, began to turn yellowish-red, and in fourteen days the whole of this and the next sheath above were covered with a white film of matted mycelium. Reddish areas, where the fungus had invaded and destroyed the tissues, were abundant, and the leaves attached to these sheaths were rapidly drying up. Sections through the red portions of the leaf-sheaths showed that the cells were penetrated by a mycelium, characterized by clamp-connexions and dark-brown, thick-walled, chlamydospore-like bodies. The control shoot gave no results. A olosely similar set of events followed when culture-mycelium, obtained from the leaf-sheaths of diseased canes, and portions of these leaf-sheaths themselves were employed. 
Experiment 2. Three two-eyed cuttings were selected from the upper part of healthy White Transparent canes, carefully washed and placed on moist coral sand, previously sterilized, in flower-pots standing in dishes containing water. These served to keep away ants. The pots were then covered with glass bell-jars and placed in a plant shed. Seven days afterwards, when the cuttings had sprouted, two of them were infected at the cut ends with mycelium (developed from a toadstool spore) similar to that used in experiment I above, and the buds were also covered therewith. The third cutting was not infected and thus served as a control. The cuttings were now covered with moist sand. In one case, in seventeen days, and in the other in twenty-nine days after infection, small white circular bodies, about the size of a pin's head, were noted at the surface of the sand on the lower leaf-sheaths of a shoot. In forty-eight hours these developed into toadstools identical with those obtained on cane-shoots attacked by root disease. On examining these shoots it was found that the lower leaf-sheaths were dead and cemented closely by white mycelium to those underneath. The outermost of those still living were covered with mycelium and showed numerous reddish areas, where the cells were found to be invaded by hyphae. The control cutting showed no infection. A similar result was obtained with culture-mycelium from the leaf-sheaths of diseased canes, and in one case toadstools appeared three weeks after infection. With portions of the leaf-sheaths from diseased canes a limited amount of infection was obtained, but no toadstools were produced and the shoots seemed to suffer little from the fungus. During this experiment the cuttings were watered, after the appearance of green leaves, with Sachs' solution.

Experiment 3. Experiment 2 was next repeated, except that sterile soil was used in the flower-pots, and the cuttings were infected when planted, and watered throughout with boiled tap-water. The developing shoots were found to be attacked by the fungus, but in one case only (when pure culturemycelium had been employed) were toadstools developed 
during the first month, at the end of which the experiment had to be discontinued. No infection was noted in the controls. In one case where pieces of leaf-sheath were used, one of the shoots became badly infected with the sclerotia fungus of Went's 'red-rot' disease. Fourteen days after infection the shoot was killed by the fungus and covered with white thread-like strands and sclerotia. The leaf-sheath employed had evidently been attacked by this fungus.

Experiment 4. A small field experiment was next carried out. During planting-time in the early part of December, I90I, the nodes and cut ends of ten healthy White Transparent cuttings were covered with actively growing mycelium, obtained originally from a toadstool spore, and planted in the ordinary way. Eight of these developed normally, but the other two were destroyed by the fungus Thielaviopsis ethaceticus, Went, the shoots dying off shortly after they appeared above ground. At the present time (August 30, 1902) the shoots from these canes are healthy and vigorous and show no trace of root disease, although white mycelium, characterized by clamp-connexions, can be seen as a matted white coating on the scale-leaves of the buds on the belowground portions of these canes.

In the early part of February, I902, ten similarly infected cuttings were planted in the same field, and were watered just sufficiently for germination to take place. After the shoots appeared above ground, the soil around the cuttings was consolidated by treading so as to render root development as difficult as possible. Little growth was made during the dry months of March and April, during which time five of the cuttings died. On examination they and their shoots were found to be penetrated by the fungus in all directions. The remainder showed no response to the rains of May and June, and when examined on August 20 were found to be throwing up shoots from below, and to exhibit all the characteristics of canes attacked by the root disease under consideration. They possessed few roots, the majority having been destroyed, during early development, by the fungus. The 
rainfall on the field during this experiment is given in the following table.

Rainfall from December, 1901, to $\mathcal{F}$ uly, 1902.

\begin{tabular}{|c|c|c|c|c|c|c|c|c|}
\hline & \begin{tabular}{c|c}
1901 \\
Dec.
\end{tabular} & Jan. & Feb. & Mar. & Apr. & May & June & July \\
\hline $\begin{array}{l}\text { Inches } \\
\text { of rain. }\end{array}$ & 4.86 & .93 & .72 & .97 & .58 & $\mathbf{3 . 9 3}$ & $\mathbf{5 . 8 0}$ & $\mathbf{5 . 3 6}$ \\
\hline
\end{tabular}

In the former case the conditions of growth were distinctly favourable, in the latter unfavourable. The canes planted in December were able to develop rapidly and to establish themselves on their own roots before the dry season. They were able to resist the fungus, although the latter maintained itself on the lower parts of the stem. In the case of the cuttings planted in February, the fungus proved too strong for the canes.

The above results clearly show that the toadstool fungus is a parasite, and that there is a genetic connexion between it and the white mycelium found on the leaf-sheaths of the canes attacked by this root disease. Moreover they serve to complete the life-history of the fungus.

\section{Some relations between the host and the parasite.}

Having established the parasitic nature of the fungus, it became possible to understand the course of the disease more clearly. As already mentioned, the malady, although occurring in first-crop canes, is a much more serious pest among rattoons, especially on the black soils of the lowland districts.

It is a general custom in Barbados to select plant-material from rattoon canes, generally from those of the second crop. The cuttings consist either of the upper part of the stem containing the main growing-point ('tops') or of the next portion, and are generally about a foot in length. The selection of plant-material from this source seems to be based partly on economic considerations, as such rattoons are poor 
in sugar, and partly on the fact that these cuttings contain four or five nodes; and thus there is a good chance of one, at least, of the buds developing. As shown in a previous paper (21) it is probable that the greater resistance of such cuttings to fungi like Thielaviopsis ethaceticus than that of cuttings from the first-crop canes, which are richer in sugar, has been unconsciously found out by experience and has helped to bring about the present practice. It appears, however, likely that planting from the worst canes must eventually lead to the degeneration of cane varieties, and a promising field for investigation seems to be indicated in which the resulting canes from the continued selection of the best and worst cuttings are compared, on an economic scale, for a number of years.

Sometimes the worst canes on the estate are selected for cuttings. In other words, the canes attacked by root disease to the greatest extent are used for the preparation of plantmaterial. On examining these canes it is found that the leafsheaths are firmly cemented to the stem by the mycelium of Marasmius, which further covers the scale-leaves of the buds as a whitish coating. The leaf-sheaths around the main growing-point which form part of the 'cane top' generally exhibit the black elliptical spore patches of Cercospora vaginae, Krüger. That both these fungi are alive was proved by cultivating the tuft of white mycelium which arose from the buds when placed in a moist chamber, and by placing the conidia of Cercospora in hanging drops. Thus these two fungi are usually planted with the host.

As previously mentioned Cercospora can be readily traced from the cutting to the mature canes.

Marasmius also follows the cane through its first year's growth, and sometimes, while the young canes suffer from drought, overcomes them and gives rise to root disease. Generally, however, the favourable conditions for rapid growth of the cuttings in December and the high condition of tilth during the first crop, enable the canes to develop normally. During this time the fungus is able to hang on, on the lower 
part of the stem, in a resting condition, where it can be seen as a white felted mass on the scale-leaves of the buds.

When, however, the canes are cut in March, and the closely packed condition of the soil combined with extreme dryness prevents anything like rapid growth of the buds at the base of the cane-stumps, the mycelium, after luxuriating in the rich substratum afforded by these stumps, is able to assert itself and master the young shoots, and thus make up for the long period of waiting. As the new shoots develop with great slowness during the dry season, the fungus has time to destroy most of the roots at the base, at the beginning of their development, and thus to give rise to the dwarfed canes so characteristic of the second crop of the lowlands. When the rains come, only a few roots are available for the supply of water and minerals, and, in spite of the liberal application of artificial manures, practically no growth results.

The fact that the fungus is not so destructive to rattoon canes on the red soils of the highland districts as to those on the black soils of the lowlands, seems to be largely due to the much greater rainfall during the dry season in the former districts than in the latter.

We can to a great extent regard the first and second crops of canes on the lowland districts of Barbados as infection experiments on a large scale with the fungus Marasmius. In the case of the first crop, conditions favour the cane and there is little disease. In the second crop, everything helps the fungus and at the same time checks the host, consequently a root disease, epidemic in character, often results. Furthermore, it is caused by a fungus which, under ordinary circumstances, can do little damage to the cane, but which, when conditions are against the host, can become a parasite and even overcome meristemmatic tissue such as that at the growing-point of the cane-root.

We have, therefore, a striking example of the influence of the environment on the result of the struggle between the host and the parasite, and a confirmation of the views brought forward on this subject by Marshall Ward (2). 


\section{Prophylaxis.}

In Java, Wakker $(10,14)$ described and figured a fungus Marasmius Sacchari, n. sp., which destroys cane-cuttings in the 'hatching beds' (Treibbeeten), in which the canes are placed before planting out, and also attacks and destroys mature canes. From his description of the fungus, which he regarded as a wound parasite, and his culture and infection experiments, there can be no doubt that the West Indian and Java forms are identical.

The conditions of cane culture in Java, however, differ markedly from those in the West Indies. In Java, cuttings are raised in special plantations on the hills, from which the cane-fields in the lowlands are planted. Great care is taken in the selection of cuttings and their protection during growth. Further, only one crop of canes is raised from the same stand, so that there are no rattoons. The fungus in Java, therefore, has less opportunity of causing a widespread root disease than is the case in some parts of the West Indies.

It is clear from the wholesale destruction of the young roots of canes attacked by this disease that there is no hope of a cure. Prevention and the assisting of the host plant as much as possible can therefore alone be aimed at.

The selection of cuttings from healthy canes and their protection during germination, instead of the present system, are essential.

Probably if the fields selected for rattooning were allowed to remain as late as possible before reaping, there would be less chance of the fungus, if present, overcoming the young shoots. Cultivation of the soil round the old stumps, as the first rains appear, ought to assist new root development. Artificial irrigation during the earlier period of growth and during drought should assist the canes to ward off the fungus.

In Surinam, an ingenious method of starving out the fungus in badly infected fields has been adopted with success by the late Mr. James Mavor. After reaping and digging up and destroying the old stumps, the field is placed under water 
for a year or two during which the fungus is destroyed. Afterwards, the water is run off, the soil allowed to dry, and a new crop of canes raised. The soil on this estate is a heavy clay, and in spite of all precautions the fungus makes its appearance in the fields after they have been in canes for four or five years. Where this method is impracticable, rotation crops would serve the same purpose.

The occurrence of rhizomorphs in connexion with this fungus suggests the advisability of isolating diseased areas by a trench from the rest of the canes, as the fungus may travel underground.

In badly diseased fields in Barbados, it is not uncommon to see healthy clumps of canes growing vigorously. Probably if these were continually selected for propagation, more resistant strains than those in use at present might be obtained.

At the present time this disease is by far the most important of the cane pests in Barbados. It also occurs in Antigua and Surinam. In addition to the losses sustained thereby, large sums of money are annually spent on artificial manures for these diseased canes which can obviously have no effect. As time goes on and the significance of the diseases of the cane is realized, reforms will no doubt be made in the local practice. Successful economic experiments on the subject, on a sufficient scale to satisfy the planter, would doubtless greatly hasten these reforms.

In conclusion, I wish to express my indebtedness to Mrs. W. G. Freeman for kindly preparing the drawings of Figs. $1,2,7,8,9$, and 14 which illustrate this paper.

\section{Summary of Conclusions.}

I. The Melanconium found on diseased sugar-canes in the West Indies is a saprophyte and is not the cause of the 'rind' disease. The whole of the evidence obtained in these experiments points to this fungus being quite distinct from Thielaviopsis ethaceticus, Went. 
2. The macro- and micro-conidial phase of Trichosphaeria Sacchari, Massee, identical with Thielaviopsis ethaceticus, Went, causes a disease of cane-cuttings in the West Indies which is the same as the 'pine-apple' disease of Java. In addition, it is a parasite on growing canes.

3. The 'rind' disease of the sugar-cane in the West Indies is identical with the 'red-smut' disease of Java, and is caused by the fungus Colletotrichum falcatum, Went. It can infect ripening canes at wounds and at old leaf-bases, and can overcome the tissues of young canes which are capable of growth and development.

4. Melanconium infects canes easily at points where they have been invaded by Colletotrichum.

5. The common root disease of the sugar-cane in Barbados is caused by the fungus Marasmius Sacchari, Wakker, the mycelium of which is able, under certain conditions, to overcome the growing-point tissues of the developing roots of the cane.

BARBADOS, Aug. 30, 1902 .

Note added :- Thanks to the kindness of Professor Marshall Ward, I have been able to repeat the culture and inoculation experiments with Melanconium and Thielaviopsis, described in this paper, at Cambridge. Both these Fungi were grown in pure culture in a cane-extract food-material at a temperature of $75^{\circ} \mathrm{F}$., and the inoculation experiments were performed on mature sugar-canes growing in the Lily-house at the Botanical Gardens. No evidence of a genetic connexion between these two forms was obtained, neither did Melanconium behave as a parasite towards the cane. On the other hand, the results were identical with those noted in the experiments in Barbados and described in the present paper. Mixed cultures of Melanconium and Thielaviopsis gave positive results when introduced into healthy canes.

The Botanical Laboratory, Cambridge.

Jan. 3, 1903 . 


\section{List of Papers Cited.}

1. I877. O. BREFELD : Unters, über Schimmelpilze III, p. I7\%

2. I890. H. MARSHALL WARD: On some relations between host and parasite in certain epidemic diseases of plants. Proc. Roy. Soc., vol. xlvii, pp. 393-443.

3. 1892. H. MARSHALL WARD: The Ginger-beer plant and the organisms composing it. Phil. Trans., vol. clxxxiii, pp. 130-2.

4. I 893. N. A. Cовв : Diseases of the Sugar-cane. Agricultural Gazette of New South Wales, vol. iv, p. 800.

5. I893. G. MASSEE : On Trichosphaeria Sacchari, Massee. Annals of Botany, vol. vii, p. $\mathbf{2} 28$.

6. I 893. F. A. F. C. Went : Het rood Snot. Mededeelingen van het Proefstation West Java.

7. 1893. F. A. F. C. Went: De Ananasziekte van het Suikerriet. Meded. van het Proefstation West Java.

8. 1894. Sugar-cane disease in Old World, Kew Bulletin, p. 8r.

9. I895. J. H. WAKKER: De stand der Suikerrietbladen bij vocht en bij droogte. Mededeelingen van het Proefstation Oost Java, Nieuw Serie, No. 3 .

10. I895. J. H. WAKKER: Eine Zuckerrohrkrankheit verursacht durch Marasmiuis Sacchari, n. sp. Centralblatt für Bakteriologie und Parasitenkunde, Abth. II, Bd. ii, pp. $45^{-56}$.

11. I895. Prillieux et Delacroix: Sur une maladie de la canne à sucre produite par le Coniothyrium melasporum (Berk.). Sacc. Bull. Soc. Mycol. de France, tom. xi, p. 75.

12. 1896. F. A. F. C. WENT: Onderzoekingen omtrent de chemische physiologie van het Suikerriet. Meded. van het Proefstation West Java, No. 25.

13. 1896. F. A. F. C. Went : Notes on Sugar-cane diseases. Annals of Botany, vol. $x$, p. $5^{8} 3$.

14. I898. J. H. WAKker and F. A. F. C. Went : De ziekten van het Suikerriet op Java.

15. 1899. W. KR ÜGER: Das Zuckerrohr und seine Kultur.

16. 1900. W. T. Thiselton-Dyer: Note on the Sugar-cane disease of the West Indies. Annals of Botany, vol. xiv, p. 609.

17. I900. A. HowARD : On Trichosphaeria Sacchari, Massee. Annals of Botany, vol. xiv, p. 6I 7 .

18. I900. ENGLer und Prantl : Die natürlichen Pflanzenfamilien, Fungi. I. Teil, i. Abteilung, pp. 403-5.

19. I90I. C. A. BARBER: Sugar-cane in the Godavari and Ganjam districts. Department of Land Records and Agriculture, Madras, vol. ii, No. 43 .

20. I901. H. TRYON: Some obstacles to successful Sugar-cane cultivation. Queensland Agricultural Journal, vol. ix, p. 85 .

21. I902. A. Howard: The field treatment of cane-cuttings in reference to fungoid diseases. West Indian Bulletin, vol. iii, No. I, p. 73. 


\title{
EXPLANATION OF FIGURES IN PLATE XVIII.
}

\author{
Illustrating Mr. Howard's paper on Diseases of the Sugar-Cane.
}

Fig. I. Portion of a sugar-cane attacked by the ' rind' disease showing stromata of $C$. falcatum above and below the leaf-base. Nat. size. At $(a)$ is a stroma of the fungus as seen under a lens.

Fig. 2. A portion of a sugar-cane, attacked by the 'rind' disease, split in half. A red blotch with a white centre is shown at $(a)$. Nat. size.

Fig. 3. Stages in the germination of a spore of $C$. falcatum in a hanging drop. The sowing was made at I p.m., Nov. 29.

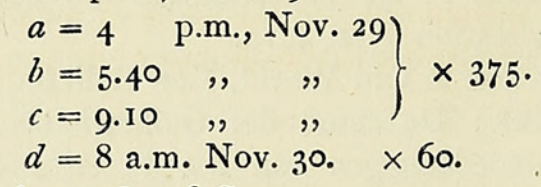

Temperature thronghout $28-3 \mathrm{I}^{\circ} \mathrm{C}$.

Fig. 4. Stages in the formation of conidia from the mycelium of C. falcatum in a hanging-drop culture. The sowing was made at I p.m., Nov. 29.

$$
\left.\begin{array}{l}
a=12.45 \text { p.m., Nov. } 3 \circ \\
b=1.30 " \| \\
c=3.50 "
\end{array}\right\} \times 375 .
$$

Temperature $29-30^{\circ} \mathrm{C}$. throughout.

Fig. 5. Production of chlamydospores on the submerged hyphae of $C$. falcatum in a hanging drop twenty-seven hours after sowing. $\times 375$.

Fig. 6. Formation of conidia of C. falcatum at stromata formed in a hanging drop. The sowing was made at I p.m., Nov. 29 , the temperature was $30-31^{\circ} \mathrm{C}$. throughout, and all are shown $\times 375$.

$$
\begin{aligned}
& a=10.25 \text { a.m., Dec. } 5 . \\
& b=12 \text { (noon) " } \\
& c=5 \text { p.m. }
\end{aligned}
$$

Fig. 7. A sugar-cane stem attacked by the fungus Marasmius Sacchari showing the aborted roots and an abnormal development of the lower buds.

Fig. 8. A portion of the below-ground part of the stem of a similarly diseased cane showing the aborted roots on a larger scale.

Fig. 9. A portion of the lower (above-ground) part of the stem of a diseased sugar-cane showing colonies of the fructifications of Marasmius Sacchari.

Fig. Io. Brown, thick-walled, usually terminal, chlamydospores in the mycelium of Marasmius.

Fig. II. Longitudinal section of a developing root of the sugar-cane destroyed by the mycelium of Marasmius. The periblem is penetrated by the fungus in all directions, many of its cells being brown in colour and much disintegrated. The root-cap is almost completely destroyed and the shaded portion of the pleurome is filled with mycelium. $\times 35$. 


\section{Sugar-Cane in the West Indies.}

Fig. I 2. Stages in the germination of a spore of the fungus in a hanging drop. The sowing was made at 2 p.m., Dec. 3 .

$$
\left.\begin{array}{l}
a=3.3 \circ \text { p.m., Dec. } 3 \\
b=4.30 \quad, " \quad, \\
c=6 \quad, \quad,
\end{array}\right\} \times 375 .
$$

Temperature throughout $29^{\circ} \mathrm{C}$.

Fig. I3. Stages in the formation of a clamp-connexion in a hanging-drop culture. The papilla in (a) arose about I00 $\mu$ from the growing-point of a hypha and the arrow indicates the direction of growth. Temperature $30^{\circ} \mathrm{C}$. throughout. (Zeiss, D D.)

$$
\begin{aligned}
& a=\mathrm{II} .4 \text { a.m., Oct. } 4 \\
& b=\mathrm{II} .7 \quad, \quad, \\
& c=\mathrm{II} .20 \quad, \quad, \\
& d=\mathrm{II} .25, \quad, \\
& e=1 \mathrm{II} .35, \text {, , } \\
& f=\mathrm{I} 2.15 \text { p.m. , }
\end{aligned}
$$

Fig. I4. Production of rhizomorphs on the walls of a culture-tube nine months after infection. Above, these bodies shade off into white feathery mycelial strands. 
Annals of Botany
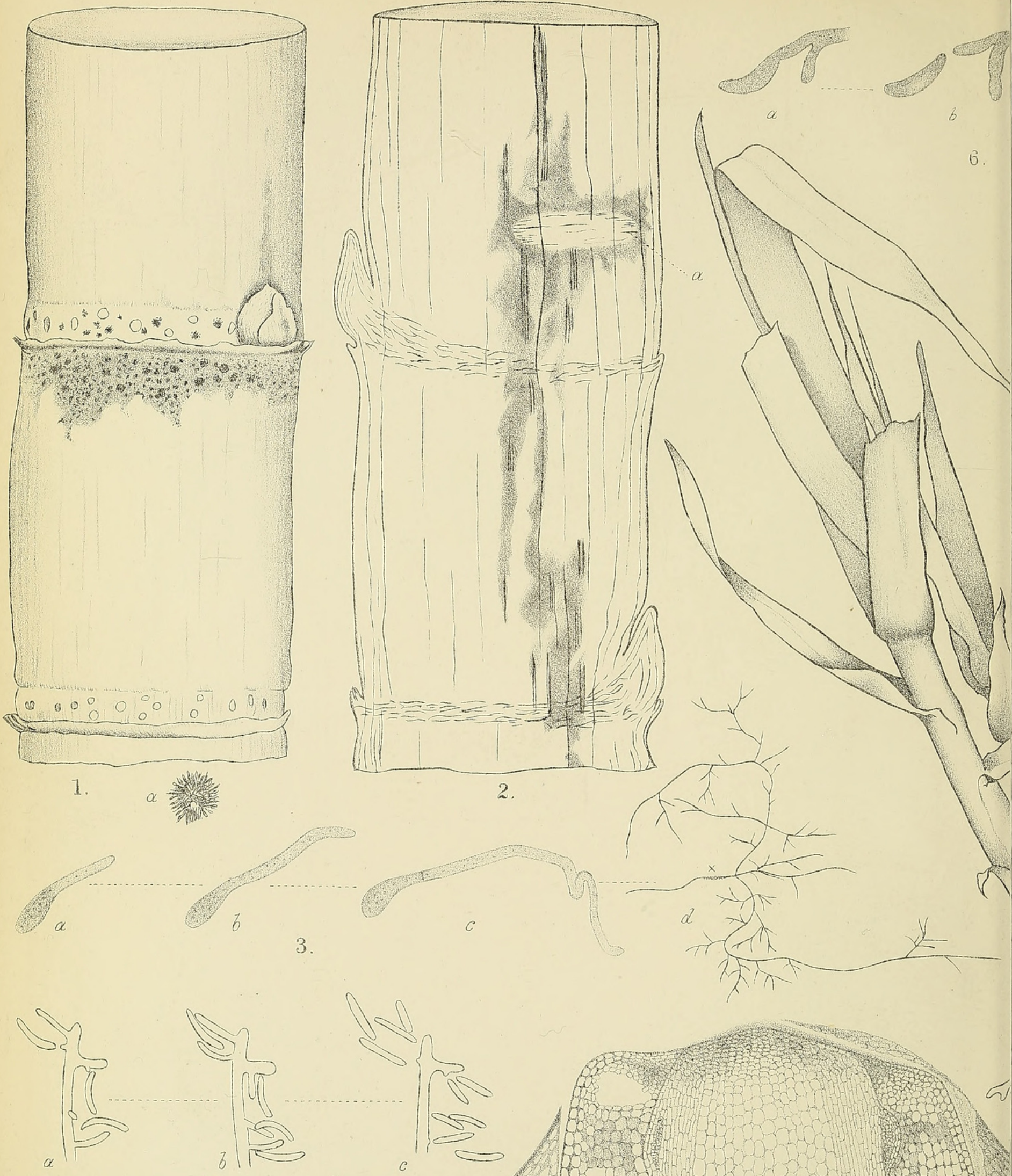

4.

(6)
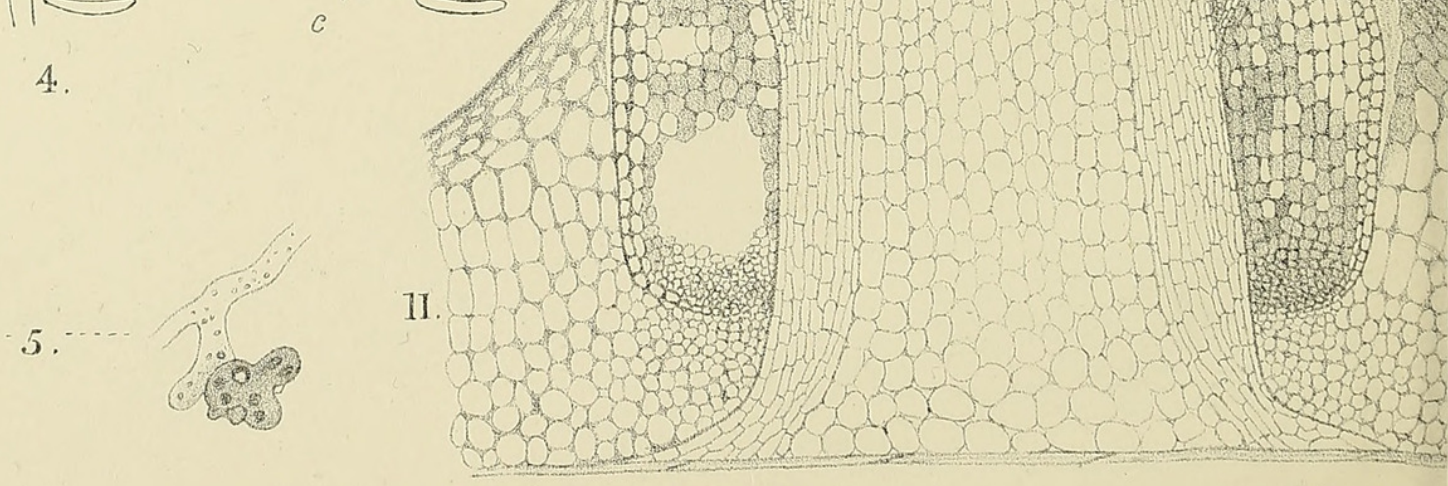

A. HOWARD. - ON SOME DISEASES OF 


\section{Annals of Botany}

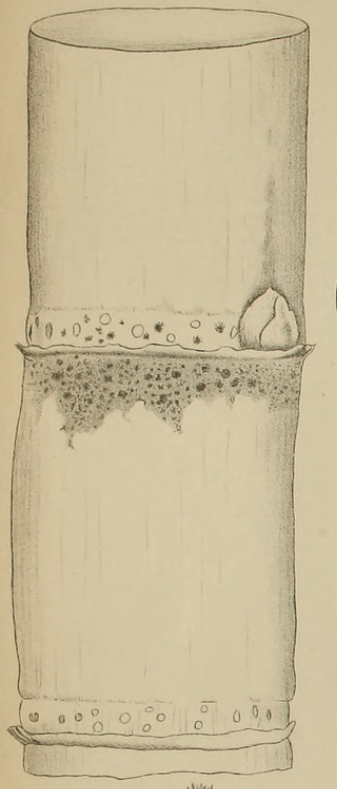

1. $\alpha$ 粪铰

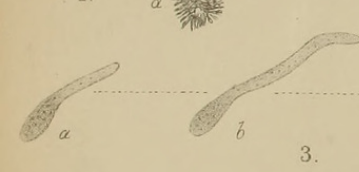

Sद

4.

(a) 8 is?
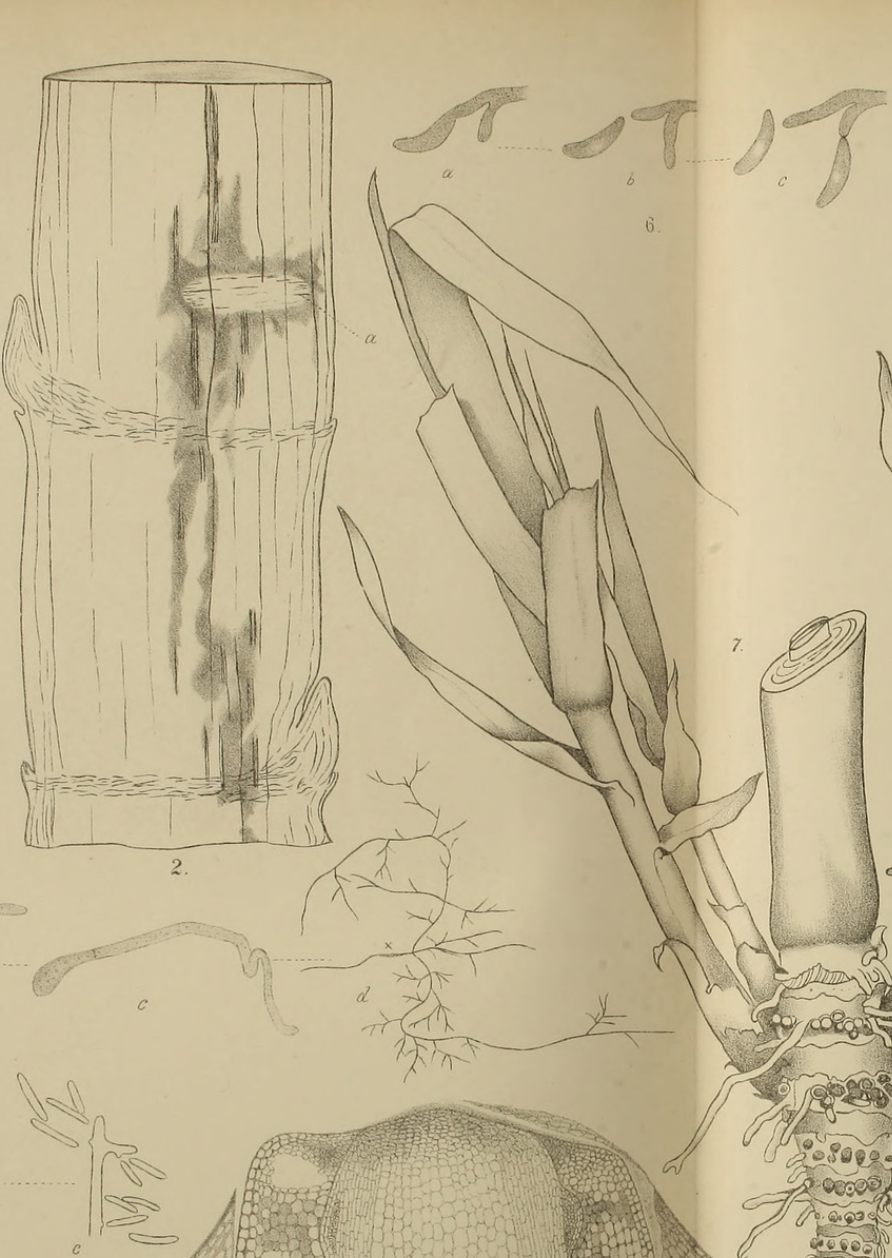

11.

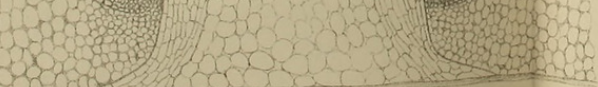

Vol. XVII, PI. XVIII.
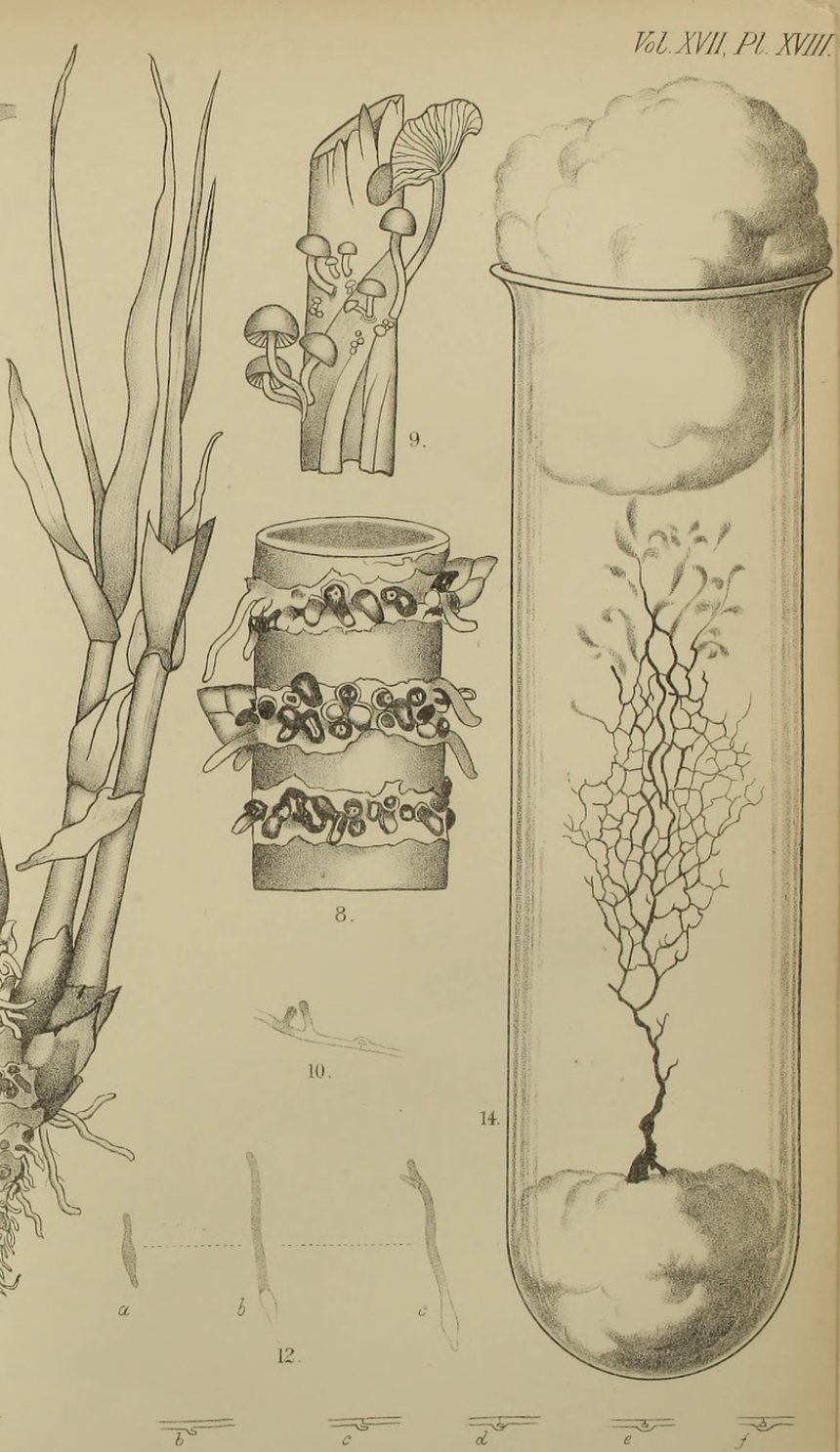

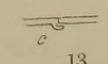

$\bar{a}^{3}$ $e^{3}$

$f^{3}$ 


\section{$2 \mathrm{BHL}$ Biodiversity Heritage Library}

Howard, Albert. 1903. "On some diseases of the sugar-cane in the West Indies." Annals of botany 17, 373-411.

https://doi.org/10.1093/oxfordjournals.aob.a088921.

View This Item Online: https://www.biodiversitylibrary.org/item/235015

DOI: https://doi.org/10.1093/oxfordjournals.aob.a088921

Permalink: https://www.biodiversitylibrary.org/partpdf/318719

\section{Holding Institution}

Smithsonian Libraries

\section{Sponsored by}

Biodiversity Heritage Library

\section{Copyright \& Reuse}

Copyright Status: Not in copyright. The BHL knows of no copyright restrictions on this item.

This document was created from content at the Biodiversity Heritage Library, the world's largest open access digital library for biodiversity literature and archives. Visit BHL at https://www.biodiversitylibrary.org. 